\title{
The Dutch Disease and the Diversification of an Economy: Some Case Studies.
}

\author{
Dr. Bitrus Nakah Bature \\ Department Of Economics, University Of Jos, Nigeria.
}

\begin{abstract}
An economy that does not seek and prepare to diversify, can equally be ready to crunch. Nations of the world have been endowed with mineral resources differently, which is why they cannot live in isolation. The argument as to whether primary resources rich nations of the world do better in economic activities or not, is a matter of whether there is diversification of their economies or not. Lack of diversification of their economies results from monoculture economic conditions. A number of countries have suffered from such crises emanating from the exploitation and development of single sectors of their economies. Part one of this work is the conceptualization of economic diversification. Development of the idea of the Dutch Disease(DD) is the part two of this work. The part three is contextualizing the DD. While, cases of the DD analysis forms our part four. The conclusion is part five which is the final section of this work.
\end{abstract}

\section{Introduction: Background}

Diversification which is all about the exploitation and development of various sectors of an economy if not all sectors, has been a major route through which many developed countries of the world passed. The discovery of certain primary materials or resources however, often change the mentality of such nations into the problem of non-diversification. The blockage to diversification comes as a result of sudden rise in revenue of such affected nations whose riches from natural resources or otherwise it's abundance, rather take them several years backward by killing their economies. In place of diversification, leaders are rather induced into corruption and wasteful spending, thereby, creating a declining economic activities, weak investments, nonchalant attitude towards reinvesting the excess income from their booming single sector. In the case of Nigeria for instance, Obasanjo(1992:2) explained that;

While Indonesia had oil in part to finance its investment in agricultural development and to use it as jump of leverage, Malaysia was not blessed with the same gift of nature. Yet the story has been told so often of how Malaysia came in the sixties to collect palm oil seedlings from Nigeria. The irony of it is that while Malaysia is currently an exporter of palm oil, Nigeria is now an importer of palm oil and importing from Malaysia.

This explains the story of declining agriculture in Nigeria as a result of concentration on a single sector (oil) for everything. The situation became more and more difficult, when rising bills from imported food and industrial machines that made Nigeria became more and more dependent on oil.

The danger of depending on a single sector began to manifest glaringly when Nigeria began to produce less than 1 million barrels of petrol daily and sold it for about $\$ 30$ per barrel as against an earlier 2.5 million barrels per day in 1979 and at a tagged price of $\$ 40$ per barrel(FGN1983). Many countries of the world has suffered from similar situation due to dependence on single growing sectors'.

The Dutch disease (DD) theory is therefore, a situation in which the discovery of primary mineral resource anywhere in the world instead of boosting exploitation and harmonious development of the economy, rather leads to decline or total collapse of economic activities in other sectors of their economies. This was the situation in the Netherland where the discovery of a large natural gas reserve led to a decline in its industrial base owing to inflationary pressure on the guilder.

The DD phenomenon created unemployment in the Netherland through a massive movement of workers from the manufacturing sector to the booming gas sector for higher pay. This action later killed their manufacturing sector. This problem did not only occurred in the Netherland, but it has occurred in so many countries of the world with different perspectives or trends leading to various difficulties. For instance, petroleum exporting countries failed into such situation especially with the occurrence of the petroleum booms of the 1973 and 1979-80. They were caught off between affluence and resources management problems.

The concentration of economic activities on a single sector can only cause more hardship and take a country several years backward. The government and/or leaders under excessive wealth and riches looses bearing due to such sudden financial power and end up calculating ways to spend such accumulated wealth. 
The term Dutch Disease was first used in an English journal called the Economist on June 26,1977 Koutassila, (1998). It tried to describe a certain phenomenon known as the Hollandis Syndrome or the Netherland Syndrome or simply the Dutch Disease Nowak, (1994). Again, Coussy, (1991:64) and Christine, (2003) also called it the ' Hollandis sickness'. The Dutch Disease existed long before the situation was actually brought to light. For instance, the collapse of the manufacturing sector and the subsequent unemployment of the Dutch economy was a clear case. Corden, (1984) explains that the abundance of gold in Australia, the growth of capital in Swiss, the growth of gold in Spain and United States of America in the $16^{\text {th }}$ century are situations or elements that constituted Dutch diseases. The fact is that countries often tend to experience serious declines in the output of other sectors of their economies, whenever the discovery of a particular sector seem to imprint in the minds of its citizens that the end has come for poverty on their land.

Thus, Al-Sabah, (1988) argued that "the DD is not unique to oil and gas exporting countries alone." The natural gas discoveries in the Netherlands in the 1960s led to an appreciation in the real exchange rate, brought about not so much by an appreciation in the nominal wage increase ahead of that of West Germany, but with the net result that her export industries were squeezed and a decline in Dutch manufacturing set in. The boom in technologically advanced parts of Japan's manufacturing sector in the 1960s had adverse effects on the less dynamic tradable sectors including agriculture. The boom in the export of Swiss bonds and money in the 1970s led to a real appreciation in the Swiss franc and had an adverse effect on traditional Swiss exports and export competing industries.

A shift of labour from the other sectors will ensue and a contraction of tradable sector will result from its reduced use of production factors due to the effect of resources movement Corden, (1982). The effects is called the supply side effect of a boom. On the demand side effect of a boom, a primary material boom, leads to increases in income at home and as such increased demand for all goods. The price of tradable is set on the world markets, the boom's extra spending raises the prices of non-tradable goods, resulting in further appreciation of the real exchange rate. Thus labour shifts from the tradable to the non-tradable sectors resulting in a contraction in the non-booming tradable sectors which is the 'spending effect'.

During the 1970s, the guilder appreciated relatives to most currencies in Europe, thereby causing both the textiles and clothing industries to almost vanish. This situation was caused by the movement of labour from the manufacturing sector to booming sector (oil and gas). There was also a decline in metal manufacturing, mechanical engineering, vehicles, ships, and even construction and building materials. The service sector expanded noticeably, and seemed to be taking over from the other sector of the economy.

\section{What Really Is The Dutch Disease?}

The term Dutch disease tried to describe a strange phenomenon which the Netherland economy was faced with after the first petroleum boom in the world. Lewis, (1989) believe that the increase in natural gas price and associated balanced of payment surpluses resulted in the appreciation of the guilder during the 1970s. This appreciation in turn worked against the manufacturing sector . Likewise Corden, (1984) stated that the Dutch Disease in the Netherlands was not the adverse effects on manufacturing or real appreciation but rather the use of booming sector revenues for social services levels which are not justifiable, but politically difficult to reduce.

Dorance and Leeson, (1997) traced the idea of Dutch disease itself back to Meade who spent six months in Australia in 1956. While there, he observed the effect of growth in Australia's resource exports, and identified what came to be called the Dutch disease Corden, (1996). Thus, the first paper actually approaching the question of the Dutch disease was by Meade and Russell, (1957). Corden, (1984) and Corden and Neary, (1982) are the cornerstone of a vast Dutch disease literature that developed around how a natural resources boom can trigger a process of "de-industrialization".

The phenomenon which also confronted the Nordic countries ( Iceland,Norway and Findland) and Australia according to Thorvaldur, (1999) and John, (1998) were best analysed as Hollandis syndrome or the model of a booming sector, signifying the relative decline in their tradable sector or productive sectors. Consequently, the DD syndrome became more complex and more general. David, (1985) described it as a phenomenon that is introduced to a country by a sudden modification in earnings from a sector which causes a contraction in other tradable goods sectors caused by the expansion on the non tradable goods sector.

Nelson, (1999) argued that, countries rich in natural resources are always exposed to DD syndrome. As such, blessings turn out to be a curse. Again, Spilimpergo, (1999) maintained that Chile and South Africa presented a contradictory situation to the hypotheses of the Dutch disease. Many countries do not show signs that we could accept the existence of the hypothesis of the DD. Such countries include Peru, Malaysia and Indonesia because they do not show the symptoms of the DD.

Therefore, a boom occurring from natural resources can be a curse and not a blessing as witnessed in some countries today Utomi, (2003:1) 'oil-curse or blessing'. Some countries like Cameroon have actually tried by concurrently diversifying the non oil sector such as agriculture in a regime of oil boom. 


\section{Contextualizing The Dutch Disease}

When a country discovers and exploits some tradable mineral resources, it becomes economically strong in terms of foreign reserves, and equally becomes capable of being developed by the earnings from such resources. Consequently, in her effort to improve and to better the life of her people, such a nation may engage in expansionary monetary policy to create a large demand for goods and services.

Accordingly, the discovery of any tradable goods truly becomes a blessing by helping a nation to face her constitutional obligations to the people. The Dutch disease theory therefore, refers to the situation in which a boom in an export sector leads to a shift of production factors towards the booming sector and an increase in the prices of non-tradable goods and services. Thus, hurting the rest of the tradable goods sector. Daniel, (1986) explains that resource curse has two main areas of active research: Political economy of mineral rent generation and distribution and general equilibrium effects of a minerals boom, including the spending effects of the mineral rents.

But some writers or schools of thought as mentioned below, believe that the discovery of natural resources such as petrol in Nigeria, gas in Netherland or forestry resource in any part of the world can be considered as a blessing and a curse. Petrol has rather impoverished so many oil exporting countries in the world today, due to the fact that harmonious exploitation and development of the various sectors of the economy would no longer be guaranteed. Amongst such writers or schools of thought are Xavier, (2003:13) 'addressing natural resources curse' Utomi, (2003:1) "managing the curse of oil” Stiglitz, (2004:1-2) "a curious phenomenon call the resources curse" and the "Dutch disease killing oil rich west Africa". Others includes, "the devil's excrement: is oil wealth a blessing or curse Utomi, (2005) Satish, (2000) Dutch disease and the crime epidemic: an investigation of mineral boom in Papua New Guinea.

A new concept of the Dutch disease called the political Dutch disease has recently been developed. Lane, (1996) and Tornell, (1999) Baland and Francois, (2000) attributed the Dutch disease to an increased rentseeking and a pernicious distributive struggle for resource rents by numerous and equally powerful groups, which result in a decline of the level of investment and in a lower growth rate

Alvarez, Cheibub, Limongi and Przeworski (ACLP, 1997) explained that three conditions must be fulfilled for a regime to be classified as democracy: the chief executive must be elected, the legislative must be elected, and there must be more than one ruling party. It follows that dictatorship is a political regime under which at least one of these three conditions is not met. It also results to political Dutch disease where natural resources or windfalls do not only lead to slower economic growth but to generate and reinforce authoritarian tendencies in third world political regimes. Such that Lane, (1999) argued that resources abundance exacerbates the power asymmetry between the populace and political elites. That part of elites' power is derived from their greater share of national income.

The impact of this is increase in income inequality with two different effects (the direct and indirect impacts). The direct impact is due to the elite's control over the government which allows them to obtain a larger share of the resource rent. The indirect impact is due to economic decline associated with the Dutch disease, which increases income inequality because the benefits from growth are more evenly distributed than resource rents. This explains why for example resource rich countries such as Nigeria, Argentina and Venezuela have been outperformed by resource poor countries such as Korea and Taiwan. Boycko, Shleifer Vishny, (1995) asked why Communist dictators such as Stalin and Kruschev were so powerful but yet not as rich as capitalist dictators such as Marcos and Mobutu. Why didn't they use their immense power to accumulate wealth? It is far more costly for communist elites to accumulate power through the private wealth than to accumulate power through the influence over the process of rent distribution because of the orientation of the type of political system they belong to. Note that dictatorship and slow growth are not the only possible outcome of resource dependence. For instance United States, Norway, Canada, and Botswana in Africa are countries where natural resources contributed to economic growth and did not undermine democracy.

This is to say the concept of diversification show that, instead of having a growth of Gross Domestic Product (GDP) from the expansion of a single sector, the diversification as used by economists will imply allowing other sectors to contribute in the growth of GDP. Such growth should be better based on all sectors rather than a booming sector. In such approach the country can avoid Hollandis Syndrome.

By this, each sector of the economy becomes relevant and important for development purpose. Any negligence to this approach gives birth to a Dutch disease. Some of the sectors that have clearly created Dutch disease situation in many countries of the world include petrol, cocoa, gas, coffee, gold, drugs, fishery, and forestry reserves. The phenomenon has affected some of the countries exporting these mineral resources mentioned above. This explains why it is said to be found in Mexico, Norway, Algeria, Nigeria Island, Zambia, Congo, Indonesia, Kuwait, Venezuela, Kazakhstan, Côte d'Ivoire, Columbia, Trinidad and Tobago, and above all Holland. Most of these countries could not take advantage of the presence of these viable sectors to develop their economies by developing other sectors in form of diversification; rather, it was the opposite. 


\section{Kazakhstan}

\section{Some Dutch Disease Cases In The World}

Karlygash, and Ali, $(2001: 4,8)$ maintained that, Kazakhstan has a lot of natural resources. The exportation of this resources and natural gas enabled her to earn rising revenue between 1995 and 2000. During this period, "the exportation of petrol rose from $23 \%$ to $52.8 \%$., while ferrous metallurgy experienced a fall from $19 \%$ in 1995 to $12.9 \%$ in 2000 ." By implication, such an economy can be vulnerable to the DD. This is so because, based on the theory of the model of hollandis syndrome, countries exporting petrol in the world increase their goods due to the rise in revenue accruing from the petroleum sector. The discoveries of a primary resource or even a progress in technology help to develop the energy sector particularly during the petroleum shock of the 1970s in some countries like Japan. Hence, we cannot explain the DD in terms of petrol or gas alone. We know that all the countries that have experienced situations of fall in certain producer's sectors due to the discovery of primary material, fall into a DD automatically.

Earlier Auty, (1998b) had equally argued that the low performance of the primary material sector of the countries that show a bad development posture are due to the following reasons:

1) The growth in exportation of these primary materials increases the inequalities of revenue which explain why there was a gap between the rich and the poor.

2) The absence of boom in the tradable goods sector, due to the existence of the Dutch Disease.

Kazakhstan has other minerals resources like iron, coal, chrome, metal, magnesium etc. But because the exploitation of petrol continued to increase yearly as follows: $6.1 \%$ in 1999, 9.4\% of the GDP in 2000 and $12.4 \%$ in 2001 Karlygash, and Ali (2001). The prediction of $14.6 \%$ in 2006 explains the presence of a Dutch Disease in her economy.

\section{Kuwait}

The potential difficulties in Kuwait that implicated the nation are the total dependence in exportation of natural resources to the international market. The impact of petrol in Kuwait has led to certain movements in real exchange rate and the relationship to the rate of sectoral inflation. Even before the invasion by Iraq in 1990, the declining status of the economy showed that the devaluation of the currency was necessary and important for major expansion in terms of industrial output Robert, (1991:1). The "pressure of petrol which had negative effects on the industrial sector was difficult to avoid as a result of petroleum boom of 1973 to1974," Bright, (1990:395). She produced a lot of fish but was still on the decline compared with the petroleum sector's activities. The result was an unharmonised development of the various sectors of the economy.

\section{Mexico}

The case of Mexico was associated with the privatisation of the "pemex petrochemicals" such that the country enjoyed an expansion in petroleum export. The situation interrupted the growth of big investment sectors for trade and to ameliorate the problem of unemployment. Thus, Auty, (1991:13) argued that;

Mexico's oil windfall was advantageously later and smaller than that of most oil exporters, but it was still absorbed too quickly. Inflation accelerated, the exchange rate appreciated and diversification into competitive non-oil tradable like resources-based industry (RBI) was retarded.

The economists called it a set of distortions that soon afflicts a country that has just passed through an oil-led expansion. The state of confusion, political in-fighting and public agitation in Mexico associated with the privatisation of pemex petrochemical plants is either a strain of the DD or a new economic virus altogether.

The Dutch disease occurs as sudden economic expansion, fuelled by an oil boom, impact on structural defects in economic and social infrastructure as well as industrial and environmental policies. Typically, too much money comes into the economy too fast causing sudden inflation and other social and economic distortions at the regional and national levels.

When the inevitable down-turn occurs in oil prices, the country is unprepared for the change in market conditions. An economic crisis occurs as the currency and national expectations-are devalued. Too much RBI investment was channelled through state enterprises-whose performance deteriorated. It relied heavily on the protected domestic market and which inadequate revenues then made RBI vulnerable as Mexico rapidly liberalized its economy in the late 1980s Auty, (1991). The general expectations in the oil exporting countries were that then oil windfall would accelerate economic growth and speed healthy structural changes. But the result was rather disappointing as political pressures for over rapid windfall absorption proved hard to resist.

\section{Columbia}

In Columbia, most of government efforts were concentrated on the prices of exports, instability of revenue source to diversify the economy, decline in terms of trade, and the crisis of balance of payment leading to the collapse of foreign market prices of primary materials. Some recent literatures on the Dutch disease such 
as Christine (2003) Emmanuel, (2005) Farooq, (2005) Joseph, (2004) suggested that some painful effects which accompanied the exports of primary materials due to booms, especially in developing countries were simply, DD.

The booming sector in Columbia was basically coffee and the export of drug realised in external trade. The industrial development in Columbia was due to a system of protectionism by a strategy of import substitution. The foreign earnings were basically from coffee export, 1961-1970. Total revenue in Columbia showed that $3 / 4$ came from export, while internal production increased the export of non tradable goods Neary and Wijubergen (1986), Edwards (1984).

The exchange rate of the country devaluated progressively while leading the export sector towards being the strongest sector, given the system of tax, the absence of custom taxes on inputs and output. This event was very efficient for Columbia. Therefore, in 1974, the contribution of coffee failed by $44 \%$ in terms of exports, while the industrial sector rose by $8 \%$ in 1967 and to $28 \%$ in 1974 . The export of coffee increased generally by $14.3 \%$ every year in real terms during the period, industrialization increased up to $27.1 \%$ in the same year.

Generally, the DD in Columbia showed in terms of relative changes in prices which concerns tradable goods and non tradable in the export sector. Hence, Columbia attained $60 \%$ export of coffee from the total export of the country. Therefore, Columbian DD was predicted from boom in primary material exports which is responsible for industrialization due to appreciation of a real exchange rate.

Kamas, (1986:1177). He summarised the symptoms of the Dutch Disease in Columbia to include:

1. Relative prices and exchange rate show that during the years of coffee boom, the relative price of home goods rose substantially.

2. Sectoral output and exports in the theory of the DD predicts that primary export boom will shrink the size of non-booming tradable goods sector through the rising relative prices of non-tradable goods and through direct resource movement effects.

3. Non-booming exports show that there is a general slower growth rate in non-coffee exports (1975-1980). The real value of exports other than coffee rose to $6.8 \%$ annually, compared with the $14.3 \%$ growth during 1967-74. The manufacturing sector grew simultaneously with only $10.5 \%$ compared to $17.1 \%$ in the booming sector. Thus, Sachs and Warner, (1995) concluded that 'one of the surprising features of modern economics growth is that economies abundant in natural resources have tended to grow slower than economies without substantial natural resources'.

\section{Cameroon}

In Cameroon, the effects of the rise in prices of petrole on the foreign exchange were the major problem to the country that presented the DD. In 1982, oil represented only $58.5 \%$ of total exports, and $56.4 \%$ in 1983. Even though, the agricultural sector was still diversifying, the rise or appreciation of its currency through exports of oil created a DD situation in the country, Koutassilla, (1998:10-14). The statistical data used in testing the reality of DD are different according to the methods of observation. Coussy, (1989) explains that in West Africa, the result of the existence of the DD or its absence is non comparable because we treat neither the concept of the syndrome nor the same happening by the instruments contracted to observe it. Three approaches for the determination of the DD in the countries as used by Coussy, (1989:64-66) which are similar to those of Nigeria, are:

1) The DD of adjustment by the rise in the nominal exchange rate;

2) The DD of adjustment by the rise in the general level of prices;

3) The DD of adjustment by the abolition of the restrictions to changes.

Congo

According to Koutassila, (1998:3) "the rise of petroleum prices in the last years of the 1970s and the beginning of the 1980s, Congo's exports has been less than that of Cameroon." This may be as a result of the concentration on the traditional sector (agriculture), because, Cameroon gave greater attention to the diversification of the traditional sector, than Congo, Cameroon was said to be free of a DD, but Congo was implicated. Recent researches have confirmed the hypothesis that foreign revenue can be a mixed blessing Utomi, (2003:2) and Stash, (2005). The almost inevitable appreciation of the real exchange rate leads to contraction of the traditional sector's export and inflation in the non traded sector.

\section{Côte D'ivoire}

Côte d'Ivoire is an open economy and segmented, which allows an analysis of the evolution of revenue distribution in rising inflation regime. This showed that the real income of workers is less sensible to accelerated inflation rate. The general aim of this theoretical analysis is to enable us understand if the coffee boom in Côte d'Ivoire could give birth to a DD phenomenon. In effect, the impact on foreign trade was noted in terms of relative decline in supply of tradable goods and its direct repercussion on exports. 
In conclusion, the empirical studies show the reaction of Ivoirien economy to the booms of coffee and cocoa which put light into the phenomenon. The country was rendered stronger from the structural adjustment programme which Côte d'Ivoire finally decided to operate a patronage of the World Bank. Nowak, (1994:51) contended that;

In the case of Cote d'Ivoire, the country suffered from the symptoms of the DD due to the coffee and cocoa booms of the late 1970s. Evidence on relative prices, growth of sectoral outputs and external trade show that the demand shocks affected the economy in the manner predicted by the DD model.

\section{The real exchange rate appreciated;}

1) The size of non booming tradable goods sector shrunk when the non tradable sector grew faster;

2) The external accounts deteriorated owing to the decline in export of non booming traded goods and the expansion of import.

\section{Spain}

According to Janvier and Antoni, (2005) the symptoms of Dutch Disease in Tourism such as Spain, are commonly associated with the discovery and development of natural resources. It can occur when forces cause a big shift in demand and high influx of foreign currency. Two Spanish regions, provides evidence that the Balearics and the Canary Islands, whose economies are heavily oriented toward tourism, both show signs of DD and the result is that their economic growth might be compromised in the future. But Van wintergreen, (1986), Usui, (1996), and Laplagne, Treadgold and Baldury, (2001) show that external aid received by developing countries tends to generate growth in consumption and an appreciation of the real exchange rate causing a decline in national production and exports by the tradeable commodities.

\section{Sâo Tome and Principe}

The discovery of oil in Sâo Tomé e Principe territorial waters and the imminent prospect of a large inflow of foreign exchange represent a huge windfall for the country but also present it with some macroeconomic policy issues and problems which can, with foresight, be ameliorated and turned to the benefit of the country in the long run Steven (2002).

\section{Papua New Guinea}

Papua New Guinea has since independence in 1975, pinned its hopes for economic development on its extractive sector. It dismissed Dutch Disease in principle, but appreciating real exchange rate which is considered to have import offsetting economic consequences via its implications for crime. According to Satish, (2000:1) the country has extraordinary mineral wealth yet its rate of economic growth has lagged behind that of other middle-income developing nations, especially compared to its neighbours in South-East Asia, and its human resources has no sign of improvement.

As Corden and Neary, (1982) Corden, (1984), Rosenberg and Saavalianen, (1998); believed that, the booming demand caused by higher wealth leads to shift of an economy's productive resources from the tradeables sector to the non-tradeables sector. Such shrinkage of the tradeables sector is known as the Dutch Disease, as it affected the Ducth manufacturing sector at the discovery of gas in the 1960s.

\section{The case of Nigeria}

The Dutch Disease in Nigeria was fully associated with the presence of oil. For this reason, Coussy, (1989:64) observer that there are:

1) the DD of adjustment by the rise in the nominal exchange rate;

2) the DD of adjustment by the rise in the general level of prices;

3) the DD of adjustment by the abolition of the restrictions to changes.

It is not a hidden fact that the above types of DD were the outcome of a booming petroleum activities that greatly influenced the Nigerian economy. The government had given more of her attention to petroleum industry as a way of raising heavy revenue, thereby neglecting other local industries that could have stimulated faster development and in a harmonious manner. For example chemical industries which fabricate chemical products and plastic materials for industrial uses have not taken off fully. It is believed that the painting industry, the detergents plastic materials, and automobile have the right to substitute important primary products for producing industrial chemicals for foreign exports. What was needed in Nigeria was sectoral diversification.

Henry, (1991) indicated that in the middle of 1980, Nigeria was the only country out of six countries (Nigeria, Indonesia, Algeria, Iran, Venezuela, Trinidad and Tobago), who's level of life quality had fallen below the shock level. The Nigerian economy was summarised into three:

1) The specific uses to which petroleum revenue was put into conditioned by the structure of socio political sharing. The social interest and class contrast was low because the state was under pressure to render services to the people which continued across military government to military government. 
2) There was no much pressure to use petroleum revenue to ameliorate agricultural sector productivity. This is where Nigeria differs with Indonesia in the study. In Indonesia, petroleum revenue was used to ameliorate agricultural sector: In Nigeria that was not done. Thus, Indonesia progressed, while Nigeria languished.

3) Macroeconomic adjustment of Nigeria had a form of lowering of the national revenue and this differs from other petroleum exporting countries. Indonesia adopted a rapid exchange rate between 1978 and 1980, in form of devaluation. Venezuela, Trinidad and Tobago experienced a large devaluation in 1981 without any hesitation on such adjustment.

Coussy, (1991:72) maintained that, While Cameroon on the other hand, seems to have escaped the DD. The potential difficulties involved in relying on primary exports has been on the export prices and revenue instability, declining terms of trade, and balance of payment crises resulting from the collapse of primary exports market prices.

The Nobel Laureate, Joseph Stiglitz, (2003:1) stated that to ensure proper management of oil revenue, leaders need to regard their country's national resources as the nation's endowment, that these resources ;

do not belong exclusively to the current government and generation, but to all citizens and generations. The current government and generation are simply trustees. To use these resources for ones own benefits, leaving future generations impoverished, is to steal their patrimony.

Management of revenue, however, has been widely observed in natural resource-rich developing countries, commonly known as the "resource curse" countries as diverse as Nigeria, Iran, and Venezuela have fallen victims to their own prosperity. Oil-rich developing countries have consistently under-performed, as compared to resource poor developing countries, in the field of human development, economic growth, human rights, democratic governance, and conflict prevention. In the same way, Utomi, (2003:1) Argued that every oil windfall has created policy shocks that have increased uncertainty and resulted in retrenchment rather than real growth of the Nigerian economy. That;

The Yom Kippur War windfall of 1973 facilitated the Udoji awards and the damage to the consumption ethic of Nigerians, which hunts us today. The Iranian revolution windfall of 1979/80 sets us up for Dutch disease after DD as expanding budget begot the open. General Licenses for imports that led us down the part of debt crisis. The ultimate was 199 windfall following the Gulf War which increased our recklessness so much that in the year of that windfall we ended up with perhaps the worst deficit we had up to that point, creating the inflationary pressures that did havoc to real incomes.

The dramatic Arab embargo of October 1973, which quadrupled world oil prices, set in motion a chain of events that was to have a great impact on the economies of virtually all countries, industrialized and developing, oil-importing and oil-exporting. Relevant questions in the case of Nigeria are:

1. How important were the oil windfalls to developing exporters?

2. Did these countries merely consume their terms of trade gains?

3. If not, what strategies did they formulate for using their new wealth to promote growth and development?

4. Did they enhance well-being and raise consumption?

5. Or did the difficulties of managing producer economics through volatile, poorly predicted terms of trade shifts nullify the potential gains, perhaps even turning it into a net loss?

6. Is it infact possible for a country receiving a large windfall gain to end up less well-off than it might have been without it?

7. What lesson can be learned from these countries experiences?

An investigation of the mineral boom in Satish, (2001) Iheanyi and Walker (1990), in their works, the impact and prospects of oil wealth in an open monocultural economy: Nigeria, a case study of oil shares of Nigerias total export earnings, 1980-87, shown below:

\begin{tabular}{|l|l|l|l|l|l|l|l|l|}
\hline Year & 1980 & 1981 & 1982 & 1983 & 1984 & 1985 & 1986 & 1987 \\
\hline $\begin{array}{l}\text { Export } \\
\text { earnings }\end{array}$ & $97.4 \%$ & $98.4 \%$ & $99.1 \%$ & $98.7 \%$ & $98.7 \%$ & $98.2 \%$ & $97.7 \%$ & $85.9 \%$ \\
\hline
\end{tabular}

Source: Oil total exports earnings. OPEC Review Vol. X111. No. 1. 1989.

Accordingly, Nelson, (1999) drew a conclusion that for a sustainable development to be achieved, countries rich in exhaustible natural resources need to consider the depletion of these resources over time and the volatility of world commodity prices in the short-run. Under the DD theory, particularly in the 1970s, showed that contrary to what common sense would indicate, natural resources are not a blessing for rich endowed countries. This particular reinterpretation gained almost general acceptance after comparing the poor economic performance of Latin America and African countries (rich in natural resources), and the economic success of the Asian tigers (poor in natural resources), in the 1970 and 1980s. Nelson, (1999) maintained that, 
some countries seem to fit the DD prediction, such as Bolivia, Nigeria, DR Congo, and Zambia. Others like Chile and South Africa, seems to contradict the DD hypothesis. Therefore the real worlds of rich-mining countries seem to be more diversified than what the DD theory predicts.

\section{Conclusion}

The characteristics of developed nations and underdeveloped ones are different, particularly when talking of development indicators. The peculiarity of the Dutch disease in this case is that most nations both developed and underdeveloped are often caught off with the flair to concentrate on the exploitation and development of their booming sector of the economy singularly. The rise in revenue always go with the desire to increase or expand spending but not for diversification. Consumption rises and investment declines. Other variables in the economy tend to be affected negatively. For instance, at the initial stage, the local currency will appreciate rapidly and depreciate greatly at a later date.

In addition to the above problem, unemployment will rise due to movement of labour from the dwindling sectors to the growing single sector. This development tends to kill other sectors of the economy. therefore, the need to diversify an economy cannot be overemphasised.

A diversified economy increases investment in the economy as more and more sectors of the economy are brought into focus with widening economic activities. Thus, the discovery of a primary materials should not be seen as a means to abandoned other relevant and important sectors of the economy as it happened in the case of those countries analysed in this work.

\section{References}

[1]. Al-Sabah, M. (1988). The "Dutch disease" in an exporting country, Kuwait', OPEC Review, summer, 1988.p.129

[2]. Alvarez, Cheibub, Limongi and Przeworski (ACLP1997). "Modernization:Theories and Facts” World Politics Vol. 49:p155.

[3]. Auty, R. M. (1990). Resource-Based industrialization: Sowing the oil in Eight Developing countries. Clarendon Press Oxford.

[4]. Auty, R. M. (1991). " Resources-based industry in a boom, downswing and liberalization: Mexico". Energy policy jan/feb .p 13.

[5]. Auty, R. M. (1998b). "Resources Abundance Economics Development: Improving the performance of Resources- Rich Countries". World Institute for Development Economics Research for action Paper No 44, 1998b.

[6]. Baland, T. and François, P. (2000). "Rent Seeking and Resource Booms". Journal of Development Economics, Vol.61, pp.527542 .

[7]. Boycko, M. Andrei, S. and Robert, V. (1995). Privatising Russia Cambridge, Mass. MIT Press.

[8]. Bright, E.O.(1990). OPEC in the third decade: an analysis of a glutted market. OPEC Review Vol.XIV, No.4.

[9]. Bright, E.O. (1991). "The oil sector and the Nigeria Currency: Perspective planning against instability. OPEC Review Vol. XV, No.1Pp.13-30.

[10]. Christine, E. Z. (2003). Le mal hollandaise : Un surplus de richesses mal géré. L'ABC de l'Economie. France \& Development mars 2003: pp.50-51.

[11]. Corden, W. M. (1984). Booming sector and Dutch Disease Economics: Survey and Consolation. Oxford Econ.. Papers 36, 3:pp.359-380.

[12]. Corden, W. (1996). “James Meade1905-1995”. Economic Record 72.217, June: 172-4.

[13]. Corden, W., and Neary, J. (1982). "Booming sector and de-industrialisation in a small open Economy." Economic journal 92, December. 825-848. Reprinted in International TradeTheory and policy : Selected Essays of Max, W. Corden, W. (ed), Aldershot: Edward Elgar, 1992.

[14]. Coussy, J. (1989). "Le conservatisme de la politique économie du Cameroon depuis l'indépendance : Origines, rationalité et conséquences", in Geschière p. et Koening, (ed).Pp, 64-66.

[15]. Coussy, J. (1991). formes spécifiques du Dutch Disease en Afrique de l'Ouest : le cas du Nigeria et du Cameroon".Revue Tiers Monde, No 125, Janvier/Mars.

[16]. Daniel, P.H.(1986). "Editorial”, IDS Bulletin, October, Mineral Exporters in Boom and Slump : 1-9.'

[17]. David, P. (1985). "problème d'ajustement consécutifs au mal néerlandais" en Afrique subsaharienne, de la crise au redressement, production minière en Afrique subsaharienne, OCDE.

[18]. Dorance, GR. And Leeson, R. (1997). “Obituary : James Edward Meade CB FBA, 1907-1995,”Economics Department Murdoch University Working Paper, No. 161, July. http://cleo.murdoch.edu.au/econs/wps/161.html

[19]. Economist, (1977). "The Dutch Disease', 26 Novembre. Zone Franc, Rapports Annuels, différentes années. Pp, 82-83.

[20]. Edwards, S. (1984). 'Coffee, Money and Inflation in Columbia, World Development, Vol.12.

[21]. Emmanuel, O. (2004). "Managing the Dutch disease in Nigeria". Analyses. OCNUS.

[22]. Emmanuel, U. U. (2003). Towards Accelerated industrial Crop Production: Problems and Prospects Bullion Vol. 26 No. 3 July/Sept 2002.

[23]. Farooq, A.(2005). Working Paper: Efficient consumption of revenues from natural resources- An application to Norwegian petroleum revenues.

[24]. F. G. N. (1983). Oil Glut-Effects on the Nigerian Economy, what you should know. Published by Federal Department of Information, public Enlightenment Division, Lagos.

[25]. Henry, (1991). Nigeria: From Windfall Gains to Welfare Looses? Sustaining Development in Mineral Economies. The resources curse thesis.

[26]. Iheanyi and Walker (1990). The Impact of prospects of oil wealth in an open monocultural economy.

[27]. Janvier, C. P. and Antoni, R. F. and Jaume, R. N. (2005). Dutch Disease in a Tourism Economic :Evidence from Spain. CRE, Documents de trebll

[28]. John, C. (1998). La politique gazière des Pays-Bas" "Dutch disease", ou maladie imaginaire ?

[29]. Joseph, E. S. (2003). Caspian oil windfalls: Who will benefit? $<$ http://www.eurasianet.org/policy_forum/crw.shtml $>$

[30]. Joseph, O.M.(2002). Policy options for the Attainment of Sustainable Electricity Supply in Nigeria. Bullion Vol. 26, No. 4 Oct/Dec. 2002.

[31]. Joseph, S. (2004). we can cure the Dutch Disease. Guardian August 18, 2004 
[32]. .Kamas, L. (1986). "Dutch disease economics and the Colombian export boom" World Development 14(9), September: 11771198.

[33]. Karlygash, K. Ali, M. K. and Wyzan, M. L. (2001). Is Kazakhstan Vulnerable to the Dutch Disease?” Working paper.

[34]. Koutassila, J. P.(1998). Syndrome hollandais: théorie et vérification empirique au Congo et au Cameroun. Centre d'économie du développement, Université Montesquieu Bordeaux IV-France.

[35]. Koutassila, J. P. (1998). Idem.p.81.

[36]. Lane, P. Aaron, T. (1996). "Power, Growth and the Voracity Effect", Journal of Economic growth, Vol.1: $213-241$.

[37]. Lane, P. and Tornel, A. (1999). “The Veracity Effect.” American Economic Review 89 (1), 22-46.

[38]. Laplagne, P.M. Treadgold and Balduury, J. (2001). "A Model od Aid Impact in some South Pacific Microstates" World Development 29: 365-383.

[39]. Lewis, S. (1984). "Development Problems of Mineral-Rich Countries", Economic Structure and Performance, edited by Syrquin, Taylor and Westphal (Orlando, Academic Press.

[40]. Meade, J. and Russel, E. (1957). "Wage Rates, the Cost of Living, and the Balance of payments",Economic Record, 33: 23-28, reprinted in the collected papers of James Meade, Vol.3, Meade, J. (1988), Howson S. (ed), Winchester, mass., London and Sydney: Unwin Hyman.

[41]. Nelson, A. (1999). "sustainble Development and Exhaustible Resources: The Dutch Disease is a disease at all", IR/PS Research Report No 99-o8. August.

[42]. Nowak, J. J. (1994). "le boom du café et du cacao en Côte d'Ivoire une étude du syndrome Néerlandais", Revue d'économie du développement. pp51- 75 .

[43]. Nowak, J. J. (1994). Syndrome Néerlandais et théorie du commerce Internationale. Economica Paris. P.18.

[44]. Obasanjo, O. (1992). “Agriculture in the Nigeria Economy and It's Financing”. New Nigeria. $22^{\text {nd }}$ p. 2

[45]. OPEC (1989). OPEC Review Vol. viii. No.1, 1989.

[46]. Robert, E.L. (1991). Diversification in a small oil exporting economy: The impact of the Dutch disease on Kuwait's industrialization.

[47]. Rosenberg, C.B and Saavalianen, T.O (1998). "How to Deal with AZerbaijans's Oil Boom and Policy Strategy in a ResourceRich Transition Economy," IMF working Paper, WP/98/6, January 1998.

[48]. Satish, C. (2000). Australian Agricultural and resources Economics Society. Inc. and Blackwell Publishers Ltd.

[49]. Satish, C. (2001). Dutch disease and the crime epidemic: an investigation of the mineral boom in Papua New Guinea. OPEC Review vol. xiv, No. 1 may.

[50]. Spilimpergo, A. A. (1999). Copper and Chilean economy: 1960-1998, IMF working paper for the World Bank

[51]. Steven, K. (2002). Dutch disease in Sâo Tomé e Principe: Policy options for the coming oil boom. Working paper. Cornell University, Ithaca, New york, USA.

[52]. Thorvaldur, (1999). Working Paper: "http://www.wider.unu.edu/publications/wp167.pdf

[53]. Usei, N. (1996). "Aid Induced structural Change in Developing Countries: An Extention of Two-Gap Model" Singapore Economic Review 41:53-66.

[54]. Utomi, P. (2003). Managing the Curse of Oil. «http://www.nigeriavillagesquarel.com/Articles/utomil.html»

[55]. Utomi, P. (2003). The curse of oil. (www.zei.de/download/zei wp/b01-29.pdf)

[56]. Xavier, S. and Arvind, S. (2003). Addressing the natural resources curse: An illustration from Nigeria. IMF Working paper. $\mathrm{Wp} / 03 / 139$. 